\title{
EVOLUTION OF ADMINISTRATIVE LAW AND ADMINISTRATIVE AND LEGAL DOCTRINE IN THE REPUBLIC OF BELARUS SINCE INDEPENDENCE
}

In Belarus, the national doctrine of administrative law has been oriented to a large extent towards the Soviet and modern Russian legal traditions, albeit with some distinct contextual features. In this work, we review the positions of some of the most authoritative scholars, and make a number of summative judgements and conclusions.

The primary aim of administrative law is to provide and create a regulatory framework for the exercise by the government authorities of their mandate and powers.

The objective of administrative law is to govern and regulate the interactions between the executive power and other legal subjects in the performance of its functions.

In the Belarusian doctrine, the predominant position of most scholars is that the scope of administrative law should include the administrative legal relations arising in the course of the exercise by the public administration bodies of their administrative functions, including of regulatory mandates towards external bodies, and in relation to the enjoyment by the citizens of their rights and liberties.

In Belarus, the system of administrative law is customarily understood as an ordered framework composed of institutions, norms and domains, which may be divided into four sections. The first section encompasses the institutions that determine the legal status in the area of public administration of the citizen, of state bodies, of non-governmental organizations and of civil servants, it also incorporate the institutions that exercise control over the subjects of administrative law.

The second section encompasses the regulations that govern liability under administrative law. The third section incorporates the norms of administrative procedure.

The fourth section includes provisions that constitute the administrative legal framework for the management of the economy, socio-cultural and other spheres.

Each section is comprised of the relevant legal institutions and sectors.

The greatest challenge for administrative law of in Belarus seems to be the definition of the administrative procedure, which has not changed since the Soviet period. The alternative propositions presented in this work are of a purely theoretical character and should eventually be superseded by a legal definition, which views it as a distinct type of legal procedure governed by the norms of administrative procedure law grounded mainly in the Code of Execution Procedure for administrative torts.

The legal term "administrative procedure" in Republic of Belarus is still identical to the concepts "administrative tort procedure" or "procedure for the hearing of administrative tort cases".

The main method of this study is that of integrated comparative analysis, with elements of the historical and formal-logical method. As a part of a comprehensive study in administrative law in the former Soviet Union, this work is intended to make a contribution to academic debate, by deepening and broadening its scope.

Key words: public administration, public authorities, executive authorities, scope of administrative law, system of administrative law, social relations, state management, administrative-public organ, administrative proceedings, branch of law, scholarship in administrative law. 


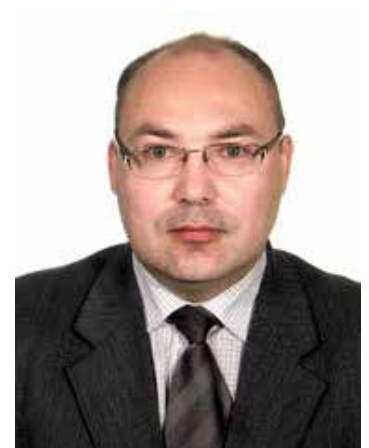

Oleg Schirinsky, Department of the Private International and European Law Belarussian State University, $\mathrm{PhD}$, Associate Professor $A B$ "Cierech, Neviadouski and Partners" orcid.org/0000-0001-6680-4560 schirinsky@cnp.by

\section{Introduction}

The scope of administrative law, administrative process, administrative jurisdiction, public administration, and executive power - these are just some of the terms that remain at the centre of an intense academic debate throughout the post-Soviet space, as the former Soviet republics turned independent states are seeking to establish their own frameworks and doctrines in administrative law by building on the legacy of the Soviet legal tradition that was in turn grounded in the administrative and legal doctrines of the Russian Empire and Roman-German legal system.

The Republic of Belarus is not an exception in this regard. Here, the legacy of the Soviet legal tradition is still strong, as is the influence of the modern Russian doctrine. Participation in a range of regional integration initiatives such as the Union State of Belarus and Russia and the Eurasian Economic Union calls for harmonization and standardization of the national legal system with that of the Union, in which the Russian Federation clearly plays a leading role. However, a number of national distinctions exist, and they are quite substantial, including with regard to notions such as scope and system of administrative law, administrative procedure and administrative jurisdiction. The Belarusian tradition of administrative law has acquired a dynamic of its own, and seems capable of emerging from the shadow of the still predominant Russian tradition and of making a distinct contribution to the development of legal science, the discipline of law and the domain of administrative law.

The aim of this study is to expose the distinct national features of the Belarusian doctrine of administrative law, to define the main elements of administrative law and to systematize them, and to outline the long-term prospects for the evolution of the administrative law as an academic field. This research appears to be particularly relevant as Belarus is entering a new era in the history of its nation state, and in the construction of a an academic and theoretical base.

The aim of the research, as indicated above, can be achieved by addressing the following research objectives:

- to identify and describe the features of the Belarusian doctrine of administrative law as distinct from the Soviet and contemporary Russian tradition of administrative law;

- to provide own definitions of the key notions of administrative law grounded in the Belarusian doctrine of administrative law; 
- to identify the prospective areas and pathways of the further evolution of administrative law in the Republic of Belarus.

The main method of this study is that of integrated comparative analysis, with elements of the historical and formal-logical method. As a part of a comprehensive study in administrative law in the former Soviet Union, this work is intended to make a contribution to academic debate, by deepening and broadening its scope.

\section{Objective and tasks of administrative law}

As specified by some of the most authoritative Belarusian scholars, administrative law combines at least three branches of law: Public administration law (otherwise termed administrative law), administrative law of torts and law of administrative execution procedure (Kramnik, Chupris, 2013: 8).

Recently, there has been a tendency in Belarus to equate the notions administrative and public administration law under the influence of the Western legal tradition, where public administration and government administration are synonymous and derive from the Latin word "administratio", which literally means "governing"; consequently, the respective areas of law are named administrative law in English, droit administratif in French, Verwaltungsrecht in German (Verwaltung - management). Remarkably, Part 1 of 2003 edition of the classic three-volume textbook "Administrative law" by A.N. Kramnik - titled "Nature of Administrative Law" was renamed in the 2013 edition (co-authored with O.I. Chupris) as "Nature of Public Administration law", with similar changes made throughout the text.

It should also be noted in this regard that "government" and "public administration" are not equivalent, as this would contradict the meaning of Article 6 of Constitution of Belarus, which stipulates the division of powers into the legislative, executive and the judiciary. Although this commonly accepted division of powers was established without regard to the historical traditions and the actual situation in the Republic of Belarus (Kramnik, Chupris, 2013: 53), the identification of executive power with public administration eliminates the distinctions between the powers altogether. In essence, this approach distinguishes only one branch of power - public administration, as public administration in the broad sense is also provided by the legislature and the judiciary.

Executive power and public administration are not in mutual opposition, but rather have a mutually dependent, connected and complementary relationship. The executive power cannot function without public administration, and likewise public administration cannot be effective without the executive power, as both constitute essential and indispensable parts of one another (Kramnik, Chupris, 2013: 56).

The primary aim of administrative law is to provide and create a regulatory framework for the exercise by the government authorities of their mandate and powers.

Therefore, the main objective of administrative law is to govern and regulate the interactions between the executive power and other legal subjects in the performance of its functions.

\section{Scope of administrative law}

In Soviet theory, the predominant and most important subject of administrative law was the state, whose interests were placed above those of the individual, while the concept of administrative law as such did not conceive in principle of the possibility of a con- 
flict between the Soviet citizen and the Soviet state acting on behalf of the people. The notion of administrative right was brought back into existence by the Attorney-General of the USSR A.Ya. Vyshinsky at the First meeting on Soviet law studies in July 1938. Although A.Ya. Vyshinsky was opposed to the idea of a legal relationship between the government and the citizen (which he viewed as a bourgeois construct), he nevertheless did not rule out the existence and evolution of administrative law on a MarxistLeninist ideological platform (Belskii, 1997: 18).

The formation in the USSR of an administrative command system of public administration made relevant the utilisation of the experience of state administration from Tsarist Russia, especially in the performance of police functions by the state administrations. As a result, the Soviet doctrine of administrative law has been based, ever since the beginning of the 1940s, on the precepts of the police law of Prussia and Russia from mid-19th century and, which were in turn reinforced for many decades was by Soviet ideological dogma (Kirin, 2012: 54). Therefore, the scope administrative law in the Soviet legal system was confined within rigid limits and did not extend beyond regulating the social relations within the USSR state administration and the exercise of administrative and executive functions (Kozlov, 1967: 5-6). Also classic was the approach to the definition of the range of administrative relations subject to administrative law based on three criteria:

1) administrative relations that arise in the context of public administration;

2) such relationships always have a state authority as a subject;

3) such relationships are relationships of power and subordination, and are characterised by the legal inequality of the parties (Kobalevskii, 1924: 30-31, 34-37).

This approach is still common to this day, testifying to the powerful inertia of the Soviet administrative law doctrine (Kononov, 2011: 3). Nevertheless, there a tendency has emerged within the Belarusian legal doctrine transgress the limitations of a narrow interpretation of the scope of administrative law. On the one hand, the administration of government in a democratic state is performed not only by the executive, but also by the legislature, the courts and directly by the citizens (Makh, 2002: 21). This kind of emancipation of an individual citizen, no longer acting only as the "object" of government, and has acquired the powers to govern directly and event "subjugate" the institutions of government to their will is a characteristic of advanced democracies. One telling example in this regard is the right of the Belarusian citizens to obtain information on the state of the environment, established by Article 74-4 of the Law "On environmental protection" (titled "Provision of information on the environment to citizens and legal entities other than bodies of government or institutions of the state") (National Assembly of the Republic of Belarus, 1992).

Upon receipt of a formal request from a citizen for information to a government authority, such authority is obliged to provide the information information requested within in the time frame provided by the law, or forward the request to a competent authority which is in possession of the such information. In this process, the citizen directly initiates the administrative procedure, and exercises some degree of direction over it (for example, by requesting additional information or making a complaint to a higher body). 
It is also true, however, that the scope of administrative law should not cover any relationship between physical persons or organisations arising in the course of their public interaction that do not directly involve an administrative body but are subject to the supervision or oversight from any such body. Because supervision and oversight from public administration covers almost any private relationship governed by the provisions of civil, labour, land and other areas of law, the scope of administrative law in this case would be extremely vague (Poliakova, 2011: 118).

Recognition of an individual's legal standing under a defined set of conditions is only a first step towards the transition to an advanced democracy. Accordingly, many authoritative Russian scholars conclude that Russia's administrative law is not fully consistent with the rule of law and an advanced civil society. A lot of work still remains to be done by the Russian legal community to develop a modern theory of administrative law, to clarify the details of a modern administrative law theory and of the notions and institutions, to identify new sub-domains of administrative law and to adjusting its framework and system (Rossinskii, Starilov, 2009: 17; Kononov, 2011: 6).

This is also true for Belarus. The Constitutional provision on the status of Belarus as a democratic, law-governed and social state and on the obligation of the state to protect the rights and liberties of individual persons have transformed the standing of an individual in administrative law relationship into that of an active subject with a legal standing (even though still incomplete, owing to the lack of an administrative apparatus). The additional function of government to provide public/social goods to citizens is also a part of public administration in a bread sense (Bentam, 1997: 556; Makh, 2002: 22). The pursuit of this socially relevant objective is dependent on the establishment of an effective legal and administrative mechanism acting, first and foremost, for the exercise of government. The circle is thus fully closed.

Therefore, the scope of administrative law in the Republic of Belarus comprises several main elements distinguished by the groups of the subjects to which they apply.

The scope of the domain of administrative law is centred around the relations between the bodies of public administration and subordinated entities in the administration of government by the executive power.

The key counterpart of the public administration bodies are the citizens of the Republic of Belarus, who exert an influence in the course of the exercise by such bodies of their administrative and legal powers. The provisions of Article 1 of the Constitution defining the status of Belarus as a democratic, law-governed and social state enables citizens to participate in the administration through direct involvement in the decision making processes, including by participating in referenda, petitioning the government authorities and appealing against the actions of administrative officials.

In consequence, the administrative legal relations that constitute the core of the scope of administrative law also arise also in the exercise by the citizens of their constitutional rights and liberties, and create a number of duties for the state if those are violated or infringed upon. In these situations, the public authorities are not engaged in the exercise of power per se, but rather in the internal organisation processes by addressing the weaknesses in administration and making public administration more effective. Therefore, the scope of administrative law should also incorporate the relations that arise 
in the administration by the public administration bodies of internal systemic functions to improve organisation and maximise performance.

In sum, the predominant position of most scholars is that the scope of administrative law should include the administrative legal relations arising in the course of the exercise by the public administration bodies of their administrative functions, including of regulatory mandates towards external bodies, and in relation to the enjoyment by the citizens of their rights and liberties (Makh, 2002: 23).

\section{System of administrative law}

Administrative law governs a distinctly varied range of relations. It is only by building a clear structure of these relations, and building a logically grounded framework - or otherwise a system of administrative law - that an in-depth study and evolution of this legal domain may be possible. In the context of a relatively stable administrative command system of the Soviet state, the widely accepted division of administrative law was into the general and the special domains. The general domain encompassed the theoretically defined institutions, while the special part addressed the mechanisms for the interaction among these institutions within specific areas and fields of government. This approach was grounded in the prevalence of the interests of the state over those of the individual person or society (Kirin, 2012: 52).

Despite the conservatism of the legal doctrine of administrative law, the imperative to seek out and build strategies to strengthen Belarusian statehood have brought to life a number of alternative perspectives and positions. A.N. Kramnik, for example, believes that the division of administrative law into the general and special domains is not fully justified or useful. In support of his view, he refers, among other things, to the disruption of the internal consistency and coherence of the administrative procedures in administrative tort cases. A.N. Kramnik is also opposed to the inclusion of administrative procedure norms in the general domain and supports their separate treatment in a dedicate sub-area of administrative law (Kramnik, 2001: 52).

In general, A.N. Kramnik proposes to group the norms of administrative law into four sections. The first section would cover the institutions which:

1) determine the legal standing of the citizen in public administration;

2) determine the legal standing of the state bodies in public administration;

3) determine the legal standing of the non-state government organisations in public administration;

4) determine the legal standing of public servants;

5) exercise control over the subjects of administrative law.

The second section encompasses the regulations that govern liabilities under administrative law.

The third section incorporates the norms of administrative procedure.

The fourth section would include provisions that constitute the administrative legal framework for the management of the economy, socio-cultural and other spheres.

Each domain is comprised of the relevant legal institutions (Kramnik, 2001: 52-53).

Alternatively, D.A. Gavrilenko and I.I. Makh suggest that the system of administrative law should be defined as a legal domain, discipline and academic subject (emphasis added), united by a common purpose and potentially acting as independent system-forming phenomena (Gavrilenko, Makh, 2004: 20). 
The common position shared by most scholars in administrative law - both Russian and Belarusian - is to view administrative law as the totality of administrative legal norms institutions and legal interactions united by a common scope and means of regulation.

Consistent with the theory of law, an administrative legal norm, like any other, has a structure consisting of a hypothesis, a disposition and a sanction. As already indicated, an administrative legal norm does not always act vertically, as is typical for the relations of subordination. An administrative law provision may apply to a contractual (or "horizontal") relationship, and may alter the legal standing of the citizen from one bound by a duty to one vested with the power to demand an action from an administrative body in the exercise of their constitutional rights and liberties.

In the most general sense, an administrative legal provision may be defined as a rule of good conduct for a public administration established by the law and sanctioned by the state authorized by the state to be applied in the administration of government by a public administration and to the exercise of the rights and duties by the citizen.

The main purpose of a provision of administrative law is to put un place a demand for the legality of actions for all actors in the sphere of public administration. However, even the actions of a public administration that do meet the formal definition of legality, may not be in conformity with the principle of legitimacy. The additional criterion here is the proportionality of an administration's actions. The criterion of proportionality is not met when the intended positive impact of an administration's actions (e. g. Maintenance of law and order) could have been achieved by measures of a less restrictive nature. For example, rather than prohibiting a public rally for security reasons, the administration should consider the possibility of moving it to a different, more appropriate location (Kanunnikova, 2015: 26; Maurer, 1999: 239).

Some fundamental principles of administrative law, as defined by the Russian scholars, include legality; basis in legal research and clarity for the general public; groundedness in the national context; federalism and coherence of the executive power; accountability and active citizenship; prevention of offences; and guaranteed help legal redress and protection of civil rights (Antonova, 1998: 8; Gavrilenko, Makh, 2004: 380). These criteria are also shared by the most authoritative Belarusian scholars, with the exception of federalism, which is replaced by the principle of unitarism typical for the Belarusian statehood model. Of key importance from the perspective of Belarusian statehood are the principles of groundedness of administrative law in the national context and coherence of the system of executive power.

Russian and Belarusian scholars alike name among the key institutions of administrative law the executive power, administrative justice, administrative procedure and administrative liability. Fundamental changes in the system of public administration during the transition to democracy and the rule of law in the Post-Soviet period led to the emergence of new institutions of administrative law, the instition for the protection individual rights and liberties. One important caveat in this regard is the probability of confusion over the meanings of legal notions that may result from the overly enthusiastic pursuit of innovation in this area. Specifically, some new institutions of administrative law announced by Russian scholars (e. g. for provision of state services, for management of state property, for delegation of state powers or for preventing corruption 
(Talapina, 2006)) have not found support within the Belarusian community of researchers in administrative law. However, Belarusian legal scholars still regard as a positive trend the emergence of complex institutions spanning several related domains of law, including administrative law (Gavrilenko, Makh, 2004: 388; Kirimova, 1998: 17-18).

\section{Administrative jurisdiction}

In Russia, the debate on what should be understood as the administrative procedure continued up until the coming into force of the Administrative Procedure Rules (APR) on 15 September 2015 (State Duma, 2015). The traditional approach - inherited from the Soviet doctrine of administrative law - is based on a very narrow definition of the administrative procedure and the relevant functions of the law enforcement agencies. The term "administrative jurisdictional activity" that was proposed by A.P. Shergin in the late 1970s and became an accepted part of the Soviet doctrine of administrative law referred to a type of law-enforcement activity by state administrations and other competent bodies in the context of the legal proceedings in cases involving administrative torts and some types of criminal offences and the making of decisions on these cases in a manner and form established by the law (Shergin, 1979: 45). A similar approach was also supported by another authoritative legal scholar, Yu.N. Starilov (Starilov, 2004: 5).

The situation changed fundamentally with the entry into force of the Administrative Procedure Rules in Russia. Article 1 of the Rules governs the administrative legal proceedings applicable to the hearing and resolution by the Supreme Court of Russia, general courts and magistrate judges of administrative cases involving allegations or disputes over the rights, liberties and lawful interests of individuals, rights and liberties of organisations, and other administrative cases arising from administrative and other public law relationships or related to judicial oversight of the legality of the exercise of official and other public authority. Previously, these types of cases were treated under civil law procedures. The new Rules made finally made a part of the Russian legal system one of the four types of judicial proceedings referred to Article 118 of the Russian Constitution of 1993, after 21 years of its enactment.

In Belarus, the situation has not changed. The Civil Procedure Code of Belarus still has a separate chapter (Chapter 29) dealing with administrative procedures (titled "Judicial procedures in cases arising from administrative legal relations"), whereby administrative legal disputes are to be treated under the civil law procedure. What is the understanding of the administrative procedure in Belarus in light of the administrative reform of 2015 in Russia?

V.A. Argues that the administrative tort procedure (in cases involving administrative torts) represents just an aspect of the administrative procedure, but the whole procedure (Kruglov, 2008).

Similarly, G.A. Vasilevich places the administrative procedure outside the limits of the administrative tort procedure. He writes: "the administrative procedure is an activity governed by administrative procedural norms involving the hearing and resolution of individual and specific cases in the area of public administration by competent subjects of administrative procedural relations with the aim of securing the rule of law and legal order (in the legal understanding)" (Vasilevich, Zabelov, Tagunov, 2013: 76). 
According to O.I. Chupris, the administrative procedure represents a totality of administrative hearings. An administrative hearing is the activity of mandated bodies of public administration and officers thereof directed towards the resolution of a range of homogeneous individual cases arising from the exercise of government and sharing a common generic attribute of social relations (Riabtsev et al., 2014). The range of administrative hearing types proposed by O. I. Chupris, unlike the list proposed by the Russian scholar Sorokin (Sorokin, 2004) does not include administrative tort hearings altogether, but includes some new types, such as hearings involving the performance of duties in civil service, administrative contractual and administrative oversight hearings. Thus, similarly to A.N. Kramnik, O.I. Chupris argues for a separate type of administrative hearing - the hearing related to the administration of government (Kramnik, Chupris, 2013). T.A. Chervyakova holds a similar view, claiming the existence of two conceptions of the administrative procedure - jurisdictional and government-related: "The first type is grounded in the understanding of the administrative procedure as an activity for resolving an administrative legal dispute or conflict". The second concept is broader and incorporates, along with the jurisdictional activity, other types of activity by the authorities of executive power pertaining to the creation and application of the law (Cherviakova, 2014: 54).

However, all of the above authors have approached the subject of administrative procedure from the perspective of legal theory. In contrast, the concept of procedures involving the exercise of government is not used in any Belarusian law or regulation. A.N. Kramnik has proposed by enact a single legal act prescribing a uniform process for the enactment and promulgation of administrative legal acts. He proposed to compile the provisions of administrative/exercise of government law in a code on treatment of individual/specific cases in the area of public administration, and the provision of procedural law in a code of proceedings in individual/specific cases in the area of public administration. A solution along these lines would have addressed multiple disputes over the notion of the administrative procedure and would have provided a legal foundation for the hearing of individual-specific cases in the area of public administration (Kramnik, 2016: 26). However, the Belarusian legislators have taken a different route. An code of execution procedure for administrative tort cases was adopted, which established a separate type of the judicial process, a process for administrative torts. Although some Belarusian scholars still believe that this type of procedure represents only one out of many aspects of the broader notion of administrative procedure (Kramnik, 2016: 26), other highly authoritative Belarusian scholars - including A.N. Kramnik and G.A. Vasilevich believe that criminal tort proceedings are not related to the administration of government (Kramnik, 2010), and that the law of execution procedure represents a totality of legal norms that govern the relations arising on account of the commission of an administrative tort (Vasilevich, Dobriian, 2014: 8).

In this regard, it seems appropriate to name a key difference in the understanding of the term "administrative process" in Belarus and Russia. In Belarus the term "Administrative procedure" is used in only one piece of legislation, the Code of Execution Procedure for Administrative Torts, referring to hearings in administrative tort cases. The 
views of G.B. Kedrov, A.N. Kramnik, O.I. Chupris, and T.A. Chervyakova cited above are purely theoretical and are pre-empted by the legal definition of the term "administrative procedure" from the Code of Execution Procedure, where it is repeated more than 400 times. Ultimately, A.N. Kramnik does admit that the administrative procedure is indeed a separate type of judicial procedure governed by the norms of administrative procedure law, of which the main source is the Code of Execution Procedure. The legal term "administrative procedure" is still identical to the concepts "administrative tort procedure" or "procedure for administrative tort cases" (Kramnik, 2016: 27). This means that Belarus is still using the concept from the late 1970s, as proposed by A.P. Shergin (Shergin, 1979: 14).

\section{Conclusions}

This study may give grounds to the following conclusions.

1. Belarus has evolved a distinct doctrine of administrative law. It is grounded in the legal tradition inherited from the Soviet period. In general, the doctrine of administrative law in Belarus can be described as highly conservative and not motivated towards fundamental change. However, the Belarusian legal doctrine has been forced to respond to the needs arising from the development of Belarus as an independent state, which has added it a new dynamic and the power to overcome the inertia of the Soviet period.

2. Within the Belarusian doctrine, most scholars define the scope of administrative law in terms of the relationships arising in the exercise by public administration bodies of their government functions. These relationships can have the character of subordination of power or relate to the internal management and organisation processes. Since the enactment of the 1994 Constitution, the scope of administrative law has included relationships pertaining to the exercise by the individual citizen of their rights and liberties, which led to the expansion of the range of subjects of administrative law, limited the power of the public administration over the citizen and vested the individual with some decision making functions.

3. Most of the Belarusian scholars have rejected traditional separation of administrative law into the general and the special domains, and make more complex and delicate distinction among its elements depending on the type of legal relationship and the nature of the parties involved. The system administrative law is defined as a totality of norms, institutions and relationships that share a common scope and method of regulation.

4. Belarusian scholars name among the key institutions of administrative law the executive power, administrative justice, administrative procedure and administrative liability. Fundamental changes in the system of public administration during the transition to democracy and the rule of law in the Post-Soviet period led to the emergence of new institutions of administrative law, the instition for the protection individual rights and liberties.

5. One key challenge for legal scholarship and administrative law is the explicit divide between the theoretical base and the legal framework over the definition of the term "administrative procedure". While the theoretical base has been evolving along the lines of the European trends and has made extensive progress, the legal framework has been stuck in the 1970s, by equating administrative procedure with the administrative tort process and the hearing of administrative tort cases. Since the enactment 
of the Administrative Procedure Rules in Russia, the administrative procedure has been uniformly understood throughout the European legal area as activity towards the resolution of an administrative legal dispute or conflict, making the gap in the Belarusian administrative law ever more visible.

6. Belarusian legislators and theorists of administrative law have yet to join their efforts to bring the Belarusian administrative law into conformity with the generally accepted European standards.

\section{Bibliography:}

1. Административное право : учебник для учреждений высшего образования / Л.М. Рябцев и др. ; под ред. Л.М. Рябцева, А.Н. Крамника, О.И. Чуприс. Минск : Издательский центр БГУ, 2014. $607 \mathrm{c}$.

2. Административное процессуально-исполнительное право : учебное пособие / под ред. Г.А. Василевича, С.В. Добрияна. Минск : Адукацыя і выхаванне, 2014. 320 с.

3. Антонова В.П. Административное право и административный процесс: старые и новые проблемы (по материалам «лазаревских чтений»). Государство и право. 1998. № 8. C. 5-32.

4. Бельский К.С. К вопросу о предмете административного права. Государство и право. 1997. № 11. С. 14-21.

5. Бентам И. Принципы законодательства. Антология мировой политической мысли : в 5 т. / отв. ред. Г.Ю. Семигин. Москва : Мысль, 1997. Т. 1 : Зарубежная политическая мысль: истоки и эволюция. С. 550-600.

6. Василевич Г.А., Забелов С.М., Тагунов Д.Е. Административное право и процесс : практикум. Минск : Право и экономика, 2013. 232 с.

7. Гавриленко Д.А., Мах И.И. Административное право Республики Беларусь : курс лекций. Минск : Дикта, 2004. 415 с.

8. Канунникова Н.Г. К вопросу о наследии Ю.М. Козлова в административно-правовой науке. Административное право и процесс. 2015. № 9. С. 25-27.

9. Киримова Е.А. Правовой институт: теоретико-правовое исследование : автореф. дисс. ... канд. юрид. наук. Саратов, 1998. 23 с.

10. Кирин А.В. О реформировании системы административного права. Журнал российского права. 2012. № 3. С. 51-56.

11. Кобалевский В.Л. Очерки советского административного права. Харьков : Госиздат Украины, 1924. 260 с.

12. Кодекс административного судопроизводства Российской Федерации : Федеральный закон от 20 февраля 2015 г. № 21-Ф3 / Государственная Дума. URL: http://www.consultant.ru/cons/cgi/online.cgi?req=doc\&base $=$ LAW \&n=314899\&fld=134\&dst=100 0000001,0\&rnd $=0.21934850853488852 \# 07692550602232977$ (дата обращения: 01.04.2019).

13. Козлов Ю.М. Предмет советского административного права. Москва : Издательство Московского университета, 1967. $160 \mathrm{c}$.

14. Кононов П.И. О предмете современного российского административного права. Административное право и прочесс. 2011. № 3. С. 2-6.

15. Крамник А.Н. Административно-деликтный процесс. Юстиция Беларуси. 2010. № 11. C. $22-26$.

16. Крамник А.Н. Административное право и государственное управление в Республике Беларусь. Минск : Амалфея, 2001. 224 с.

17. Крамник А.Н. Административный процесс и его стадии: теоретико-правовые проблемы. Юстииия Беларуси. 2016. № 4. С. 25-29. 
18. Крамник А.Н. Курс административного права Республики Беларусь. Минск : Тесей, 2002. $608 \mathrm{c}$.

19. Крамник А.Н., Чуприс О.И. Административное право в Республике Беларусь : в 2 ч. Минск : Издательский центр БГУ, 2013. Ч. 1 : Управленческое право. 566 с.

20. Круглов В.А. Административный (административно-деликтный) процесс в Республике Беларусь. 2-е изд. Минск : Амалфея, 2008. 395 с.

21. Мах И.И. Аб прадмеце адміністрацыйнага права. Весиі Наџыянальнай акадэміі навук Беларусі. Серыя «Гуманітарных навук». 2002. № 3. С. 19-23.

22. Мах И.И. Об отдельных аспектах административно-правового спора. Право.by. 2017. № 4. С. 48-53.

23. Об охране окружающей среды : Закон Республики Беларусь от 26 ноября 1992 г. № 1982-XII / Национальное собрание Республики Беларусь. URL: http://pravo.by/ document/?guid=3871\&p0=v19201982 (дата обращения: 01.04.2019).

24. Полякова Л.А. О некоторых вопросах определения предмета административного права. Закон и право. 2011. № 4. С. 115-119.

25. Россинский Б.В. Наследие Ю.М. Козлова как основа современного понимания предмета административного права. Административное право и проиесс. 2015. № 9. С. 14-21.

26. Россинский Б.В., Старилов Ю.Н. Административное право : учебник. 4-е изд. Москва : Норма, 2009. 670 с.

27. Сорокин В.Д. Административно-процессуальное право : учебник. Санкт-Петербург : Юридический центр Пресс, 2004. 550 с.

28. Старилов Ю.Н. Административный процесс в системе современных научных представлений об административной юстиции. Государство и право. 2004. № 6. С. 5-13.

29. Талапина Э.В. Новые институты административного права. Государство и право. 2006. № 5. С. 14-21.

30. Червякова Т.А. Теоретико-прикладные проблемы лицензирования в Республике Беларусь. Минск : БНУ, 2014. 155 с.

31. Шергин А.П. Административно-юрисдикционная деятельность. Москва : Юридическая литература, 1979. 144 с.

32. Maurer H. Allgemeines Verwaltungsrecht. 12. Aufl. München : C.H. Beck, 1999. 835 s.

\section{References:}

1. Riabtsev, L.M., Kramnik, A.N., Chupris, O.I. (eds.) (2014). Administrativnoe pravo: uchebnik dlia uchrezhdenii vysshego obrazovaniia [Administrative law: textbook for higher education institutions]. Minsk: Izdatelskii tsentr BGU [in Russian].

2. Vasilevich, G.A., Dobriian, S.V. (eds.) (2014). Administrativnoe protsessualno-ispolnitelnoe pravo: uchebnoe posobie [Administrative procedure law: a training manual]. Minsk: Adukatsyia i vykhavanne [in Russian].

3. Antonova, V.P. (1998). Administrativnoe pravo i administrativnyi protsess: starye i novye problemy (po materialam "lazarevskikh chtenii") [Administrative law and administrative process: old and new problems (based on "Lazarev readings")]. Gosudarstvo i pravo, no. 8, pp. 5-32 [in Russian].

4. Belskii, K.S. (1997). K voprosu o predmete administrativnogo prava [On the subject of administrative law]. Gosudarstvo i pravo, no. 11, pp. 14-21 [in Russian].

5. Bentam, I (1997). Printsipy zakonodatelstva [Principles of legislation]. Antologiia mirovoi politicheskoi mysli: $v 5$ tomakh / ed. by G.Iu. Semigin. Moscow: Mysl, vol. 1: Zarubezhnaia politicheskaia mysl: istoki i evoliutsiia [Foreign political thought: origins and evolution], pp. 550-600 [in Russian]. 
6. Vasilevich, G.A., Zabelov, S.M., Tagunov, D.E. (2013). Administrativnoe pravo i protsess: praktikum [Administrative law and process: workshop]. Minsk: Pravo i ekonomika [in Russian].

7. Gavrilenko, D.A., Makh, I.I. (2004). Administrativnoe pravo Respubliki Belarus: kurs lektsii [Administrative law of the Republic of Belarus: course of lectures]. Minsk: Dikta [in Russian].

8. Kanunnikova, N.G. (2015). K voprosu o nasledii Iu.M. Kozlova v administrativno-pravovoi nauke [To the question of the heritage of Yu.M. Kozlov in administrative law science]. Administrativnoe pravo i protsess, no. 9, pp. 25-27 [in Russian].

9. Kirimova, E.A. (1998). Pravovoi institut: teoretiko-pravovoe issledovanie [Law institute: theoretical and legal research] (Extended abstract of candidate's thesis). Saratov [in Russian].

10. Kirin, A.V. (2012). O reformirovanii sistemy administrativnogo prava [On reforming the administrative law system]. Zhurnal rossiiskogo prava, no. 3, pp. 51-56 [in Russian].

11. Kobalevskii, V.L. (1924). Ocherki sovetskogo administrativnogo prava [Essays on Soviet administrative law]. Kharkov: Gosizdat Ukrainy [in Russian].

12. State Duma (2015). Kodeks administrativnogo sudoproizvodstva Rossiiskoi Federatsii: Federalnyi zakon ot 20 fevralia 2015 g. № 21-Ф3 [Code of Administrative Procedure of the Russian Federation: Federal Law of February 20, 2015 № 21-Ф3]. Retrieved from: http:// www.consultant.ru/cons/cgi/online.cgi?req $=$ doc \&base $=$ LAW $\& n=314899 \&$ fld $=134 \&$ dst $=100000$ $0001,0 \&$ rnd $=0.21934850853488852 \# 07692550602232977$ [in Russian].

13. Kozlov, Iu.M. (1967). Predmet sovetskogo administrativnogo prava [The subject of Soviet administrative law]. Moscow: Izdatelstvo Moskovskogo universiteta [in Russian].

14. Kononov, P.I. (2011). O predmete sovremennogo rossiiskogo administrativnogo prava [On the subject of modern Russian administrative law]. Administrativnoe pravo i protsess, no. 3, pp. 2-6 [in Russian].

15. Kramnik, A.N. (2010). Administrativno-deliktnyi protsess [Administrative and tort process]. Iustitsiia Belarusi, no. 11, pp. 22-26 [in Russian].

16. Kramnik, A.N. (2001). Administrativnoe pravo i gosudarstvennoe upravlenie v Respublike Belarus [Administrative law and public administration in the Republic of Belarus]. Minsk: Amalfeia [in Russian].

17. Kramnik, A.N. (2016). Administrativnyi protsess i ego stadia: teoretiko-pravovye problemy [Administrative process and its stages: theoretical and legal problems]. Iustitsiia Belarusi, no. 4, pp. 25-29 [in Russian].

18. Kramnik, A.N. (2002). Kurs administrativnogo prava Respubliki Belarus [Administrative law course of the Republic of Belarus]. Minsk: Tesei [in Russian].

19. Kramnik, A.N., Chupris, O.I. (2013). Administrativnoe pravo v Respublike Belarus: v 2 chastiakh [Administrative law in the Republic of Belarus: in 2 parts]. Minsk: Izdatelskii tsentr BGU, part 1: Upravlencheskoe pravo [in Russian].

20. Kruglov, V.A. (2008). Administrativnyi (administrativno-deliktnyi) protsess v Respublike Belarus [Administrative (administrative and tort) process in the Republic of Belarus]. 2nd ed. Minsk: Amalfeia [in Russian].

21. Makh, I.I. (2002). Ab pradmetse administratsyinaga prava [On the subject of administrative law]. Vestsi Natsyianalnai akademii navuk Belarusi. Seryia "Gumanitarnykh navuk", no. 3, pp. 19-23 [in Belarusian].

22. Makh, I.I. (2017). Ob otdelnykh aspektakh administrativno-pravovogo spora [On certain aspects of the administrative dispute]. Pravo by, no. 4, pp. 48-53 [in Russian].

23. National Assembly of the Republic of Belarus (1992). Ob okhrane okruzhaiushchei sredy: Zakon Respubliki Belarus ot 26 noiabria 1992 g. № 1982-XII [On Environmental Protection: Law of the Republic of Belarus of November 26, 1992 № 1982-XII]. Retrieved from: http://pravo.by/ document/?guid=3871\&p0=v19201982 [in Russian]. 
24. Poliakova, L.A. (2011). O nekotorykh voprosakh opredeleniia predmeta administrativnogo prava [On some issues of determining the subject of administrative law]. Zakon $i$ pravo, no. 4, pp. 115-119 [in Russian].

25. Rossinskii, B.V. (2015). Nasledie Iu.M. Kozlova kak osnova sovremennogo ponimaniia predmeta administrativnogo prava [The legacy of Yu.M. Kozlov as the basis of modern understanding of the subject of administrative law]. Administrativnoe pravo i protsess, no. 9, pp. 14-21 [in Russian].

26. Rossinskii, B.V., Starilov, Iu.N. (2009). Administrativnoe pravo: uchebnik [Administrative law: textbook]. 4th ed. Moscow: Norma [in Russian].

27. Sorokin, V.D. (2004). Administrativno-protsessualnoe pravo: uchebnik [Administrative procedure law: textbook]. Saint Petersburg: Iuridicheskii tsentr Press [in Russian].

28. Starilov, Iu.N. (2004). Administrativnyi protsess v sisteme sovremennykh nauchnykh predstavlenii ob administrativnoi iustitsii [Administrative process in the system of modern scientific ideas about administrative justice]. Gosudarstvo i pravo, no. 6, pp. 5-13 [in Russian].

29. Talapina, E.V. (2006). Novye instituty administrativnogo prava [New institutions of administrative law]. Gosudarstvo i pravo, no. 5, pp. 14-21 [in Russian].

30. Cherviakova, T.A. (2014). Teoretiko-prikladnye problemy litsenzirovaniia v Respublike Belarus [Theoretical and applied problems of licensing in the Republic of Belarus]. Minsk: BNU [in Russian].

31. Shergin, A.P. (1979). Administrativno-iurisdiktsionnaia deiatelnost [Administrative jurisdictional activity]. Moscow: Iuridicheskaia literatura [in Russian].

32. Maurer, H. (1999). Allgemeines Verwaltungsrecht [General administrative law]. 12. Aufl. München: C.H. Beck [in German].

\title{
РОЗВИТОК АДМІНІСТРАТИВНОГО ПРАВА, АДМІНІСТРАТИВНОЇ ТА ПРАВОВОЇ ДОКТРИНИ В РЕСПУБЛЦЦ БІЛОРУСЬ ПІСЛЯ ЗДОБУТТЯ НЕЗАЛЕЖНОСТІ
}

\author{
Олег Ширінський \\ кафедра міжнародного приватного \\ ієвропейського права, \\ Білоруського державного університету \\ кандидат юридичних наук, доцент. \\ АБ «Терех, Неведовскій і партнери» \\ orcid.org/0000-0001-6680-4560 \\ schirinsky@cnp.by
}

У Республіці Білорусь створена національна школа адміністративного права, яка орієнтована значною мірою на радянську та сучасну російську школу права, проте має свої особливості. У роботі розглянуто думки найбільш авторитетних учених та на основі изьго зроблено узагальнюючі висновки.

Первинна мета адміністративного права - забезпечення нормативної бази та створення правової основи, необхідної для здійснення органами державного управління свойх владних повноважень.

Основне завдання адміністративного права полягає в регулюванні й упорядкування відносин виконавчої влади з іншими суб'єктами права в ході здійснення нею функції державного управління. 
До предмета адміністративного права в білоруській доктрині більиість учених відносять адміністративно-правові відносини, щуо виникають у прочесі виконання органами публічної адміністрачії функцій державного управління, які мають як зовнішній підпорядковановладний, так і внутрішньоорганізачійний характер, а також відносини, пов'язані $з$ реалізацією громадянами своїх прав і свобод.

Система адміністративного права в Республіці Білорусь традиційно розуміється як упорядкована структура, що складається з інститутів, норм і галузей, які можна розділити на чотири частини.

До першої частини включені інститути, які визначають правовий статус громадян y сфері державного управління, державних органів у сфері державного управління, недержавних організацій у сфері державного управління та державних службовців, а також забезпечують контроль за суб' єктами адміністративного права.

У другій частині об'єднані норми, що регулюють відповідальність з адміністративного права. У третій частині розташовані норми адміністративного прочесу.

До четвертої частини включені норми, щзо визначають адміністративно-правові основи управління економікою, сочіально-культурною та іншими сферами.

Кожна частина при цьому складається з відповідних правових інститутів і галузей.

Найбільш гострим дефіцитом адміністративного права Республіки Білорусь є застигле ще в радянський період визначення адміністративного прочесу. Наведені в роботі альтернативні судження мають виключно теоретичний характер і повинні поступитися легальній дефініції адміністративного прочесу, згідно з якою ие самостійний вид юридичного прочесу, урегульований нормами адміністративного процесуального права, основним джерелом яких є Прочесуально-виконавчий кодекс про адміністративні правопорушення Республіки Білорусь.

Правовий термін «адміністративний прочес» у Республічі Білорусь досі тотожний поняттям «адміністративно-деліктний процес» $i$ «процес у справах про адміністративні правопорушення».

Основним методом дослідження є комплексний порівняльний аналіз із використанням історичного та формально-логічного методів. Як частина всеосяжного дослідження в галузі адміністративного права на пострадянському просторі, ия робота покликана зробити свій внесок у науковий обмін, сприяючи його поглибленню й розширенню.

Ключові слова: публічне адміністрування, органи державної влади, органи виконавчої влади, об'єкт адміністративного права, система адміністративного права, суспільні відносини, державне управління, адміністративно-громадський орган, адміністративне судочинство, галузь права, адміністративно-правова наука. 